Vol. 1 No. 4 Oktober 2021 e-ISSN : 2774-6283 | p-ISSN : 2775-0019

\title{
PENERAPAN MODEL TEAM ASSISTED INDIVIDUALIZATION UNTUK MENINGKATKAN HASIL BELAJAR PASSING BOLA BASKET KELAS X UPW SMK 4 MATARAM 2018
}

\author{
I KETUT WARA' \\ SMK Negeri 4 Mataram, \\ Email : ketutwara@gmail.com
}

\begin{abstract}
ABSTRAK
Penelitian ini bertujuan Untuk megetahui efektivitas penerapan model pembelajaran kooperatif tipe Team Assisted Individualization (TAI) dalam pembelajaran passing pada permainan bola basket. Metode Penelitian ini tergolong penelitian tindakan kelas (classroom action research) rancangan penelitian ini menggunakan siklus yang terdiri dari perencanaan, pelaksanaan, observasi/evaluasi, dan refleksi. Subyek penelitian adalah siswa kelas X UPW SMK Negeri 4 Mataram yang berjumlah 42 orang terdiri dari 22 siswa putra dan 20 orang siwa putri. Dalam penelitian ini dilakukan selama 2 siklus. Masing-masing siklus terdiri dari 3 kali pertemuan. Pada siklus 1 penguasan materi siklus secara individu dan klasikal masih sangat kurang karena persentase keaktipan siswa baru mencapai $75 \%$ sedangkan asesment yang dijalankan guru baru $80 \%$ belum mencapai $100 \%$. Data dianalisis menggunakan stastik deskriptif dengan pencapaian penguasan materi $70 \%$ secara individu dan $75 \%$ secara klasikal. Hasil analisis data diperoleh bahwa di siklus I tingkat penguasaan materi siswa secara klasikal adalah72,6\% yangberada pada katagori sangat kurang dan siklus II tingkat penguasaan materi secara klasikal adalah $92 \%$ yang berada kategori sangat baik. jadi hasil belajar secara klasikal dari siklus I ke siklus II peningkatannya $25 \%$.
\end{abstract}

Kata Kunci : Model Pembelajaran TAI dan Hasil Belajar Passing

\section{ABSTRACT}

This study aims to determine the effectiveness of the application of the Team Assisted Individualization (TAI) cooperative learning model in learning passing in basketball games. This research method is classified as classroom action research. This research design uses a cycle consisting of planning, implementation, observation/evaluation, and reflection. The subjects of the research were students of class X UPW SMK Negeri 4 Mataram, totaling 42 people consisting of 22 male students and 20 female students. This research was conducted for 2 cycles. Each cycle consists of 3 meetings. In cycle 1, mastery of individual and classical cycle materials was still lacking because the percentage of student activity had only reached $75 \%$, while the assessment carried out by the teacher was only $80 \%$ not yet $100 \%$. Data were analyzed using descriptive statistics with the achievement of mastery of the material $70 \%$ individually and $75 \%$ classically. The results of data analysis showed that in the first cycle the students' mastery level of classical material was $72.6 \%$ which was in the very poor category and in the second cycle the classical level of mastery of the material was $92 \%$ which was in the very good category. so learning outcomes classically from cycle I to cycle II increase by $25 \%$.

Keywords: TAI Learning Model and Passing Learning Outcomes

\section{PENDAHULUAN}

Pembelajaran permainan bola basket akan dapat dikatagorikan berhasil, apabila setiap pemain mampu memainkan dengan baik dan benar, serta mencerminkan keseriusan bermain (Depdiknas, 2002: 14). Setiap cabang olah raga memiliki karakteristik yang berbeda baik dari segi peraturan permainan, jumlah pemain dan bagaimana cara memainkannya. Demikian pula pada permainan bola basket, perbedaan tersebut berkonsekuensi pada perlunya persyaratan untuk mampu memainkannya dengan baik. Penguasaan teknik dasar yang kuat dan benar merupakan faktor penting dalam peningkatan dan pengembangan hasil belajar. Adapun teknik dasar dalam permainan bola basket adalah lempar tangkap (passing and chatching), teknik 
menembak (shooting), dan teknik dasar menggiring bola (drebbling) (Sarumpaet, dkk 1992: 223), karena dalam kurikulum pendidikan jasmani permainan bola basket termasuk kegiatan pokok dari mata pelajaran pendidikan jasmani baik di tingkat SMP maupun di tingkat SMK adalah siswa maupun bermain bola basket sesuai dengan teknik dasar yang lebih dikembangkan.

Mengingat penguasaan teknik dasar permainan bola basket adalah bagian paling penting yang dikuasai oleh siswa SMK atau sederajat, guru pendidikan jasmani seyogyanya mampu menciptakan situasi belajar yang menyenangkan, dan mudah diterima oleh siswa yang memiliki kemampuan yang tinggi, sedang maupun siswa berkemampuan rendah. Hal tersebut dapat dilakukan dengan cara menerapkan metode dan teknik belajar yang tepat, serta dengan menerapkan model pendekatan-pendekatan pelajaran selaras dengan perkembangan ilmu pengetahuan.

Sesuai dengan hasil observasi awal penelitian SMK Negeri 4 Mataram pada siswa kelas $\mathrm{X}$ UPW, dalam pembelajaran pendidikan jasmani menunjukkan bahwa banyak siswa yang belum benar melakukan teknik passing dalam permainan bola basket, hal ini disebabkan karena siswa merasa takut untuk melakukannya karena bolanya berat dan keras. teknik-teknik dasar dalam permainan bola basket belum di pahami karena harus menunggu perintah guru, siswa kurang memperhatikan penjelasan dan contoh gerakan yang benar, kurangya sarana dan prasarana serta jam pelajaran yang terbatas sehingga siswa lebih banyak pasif saat berlangsungnya proses pembelajaran. Kondisi seperti ini jelas menghambat perolehan hasil belajar yang maksimal.

Berdasarkan uraian di atas, penulis menerapkan salah satu alternatif pemecahan masalah yaitu degan menerapkan model pembelajaran kooperatif tipe Team Assisted Individualization (TAI) yang bertujuan untuk menggajak siswa lebih berperan aktif dalam peroses pembelajaran. Pada metode pembelajaran ini, siswa belajar dengan kelompok kecil untuk mempelajari materi yang diberikan. Selanjutnya siswa diajak satu permainan akademis, untuk mengetahui sejauh mana siswa menguasai materi tiap kelompok. Permainan ini dapat berfungsi sebagai latihanlatihan sebelum siswa mengikuti tes individual.

Adanya permainan akademik dalam pembelajaran kooperatip tipe tim assisted individualization dapat menimbulkan rasa tangung jawab siswa untuk memberikan kontribusi positif pada kelompoknya. Dengan demikian, siswa akan berusaha untuk dapat menguasai materi dengan sebaik-baiknya sehingga degan cara tidak langsung permainan akademik tersebut dapat meningkatkan motivasi siswa untuk mengikuti proses belajar mengajar sehingga nantinya dapat berpengaruh terhadap hasil belajar.

Berdasarkan uraian tersebut di atas, peneliti merasa terdorong untuk melaksanakan penelitian yang berjudul: penerapan model pembelajaran kooperatif tipe Team Assisted Individualization (TAI) untuk meningkatkan hasil belajar passing dalam permainan bola basket pada siswa kelas X UPW SMK Negeri 4 Mataram tahun pelajaran 2017/2018.

\section{METODE PENELITIAN}

Metode Penelitian ini tergolong penelitian tindakan kelas (classroom action research) rancangan penelitian ini menggunakan siklus yang terdiri dari perencanaan, pelaksanaan, observasi/evaluasi, dan refleksi. Subyek penelitian adalah siswa kelas X UPW SMK Negeri 4 Mataram yang berjumlah 42 orang terdiri dari 22 siswa putra dan 20 orang siwa putri. Dalam penelitian ini dilakukan selama 2 siklus. Masing-masing siklus terdiri dari 3 kali pertemuan. Bentuk penilaian menggunakan penilaian Proses dengan menggunakan Asesment Passing Chest pass dan Asesmen passing Bounce pass dan juga menggunakan asesmen observasi guru dan asesmen Observasi siswa

\section{HASIL DAN PEMBAHASAN}

Berikut ini data hasil observasi kegiatan yang telah dilakukan oleh guru maupun kegiatan yang muncul dari asesmen keaktifan siswa selama proses pembelajaran di siklus I 
Tabel 1. Akumulasi hasil Pengamatan Observer pada proses pembelajaran chest pass siklus I.

\begin{tabular}{|l|l|l|l|}
\hline NO & Kegiatan Observer & $\begin{array}{l}\text { Aktivitas kegiatan } \\
\text { Guru 20 Asesmen }\end{array}$ & $\begin{array}{l}\text { Aktivitas kegiatan } \\
\text { Siswa15 Asesmen }\end{array}$ \\
\hline 1 & $\begin{array}{l}\text { Prosentase akumulasi } \\
\text { Asesmen yang muncul } \\
\text { menurut Observer siklus I } \\
\text { pada pertemuan 1 }\end{array}$ & Tercapai 10=50\% & Tercapai 8,1=54\% \\
\hline 2 & $\begin{array}{l}\text { Prosentase akumulasi } \\
\text { Asesmen yang muncul } \\
\text { menurut Observer siklus I } \\
\text { pada pertemuan 2 }\end{array}$ & Tercapai 14=70\% & Tercapai 9,1=60,6\% \\
\hline 3 & $\begin{array}{l}\text { Prosentase akumulasi } \\
\text { Asesmen yang muncul } \\
\text { menurut Observer siklus I } \\
\text { pada pertemuan 3 }\end{array}$ & Tercapai 16=80\% & $\begin{array}{l}\text { Tercapai 10,9= } \\
72,67 \%\end{array}$ \\
\hline
\end{tabular}

Dari hasil analisa kegiatan yang dilakukan guru pada siklus I, baik pada pertemuan pertama, kedua maupun ketiga belum mencapai target $85 \%$. Jadi guru masih harus memperhatikan cara penyampaian materi passing dalam permainan bola basket. Berdasarkan rekomendasi dari observer guru harus memperbaiki langkah pembelajaran agar terjadi perubahan hasil belajar siswa ( data ada pada lampiran)

Cara penskoran deskriptor kegiatan siswa

- $\quad$ Skor 1 diberikan jika $X \leq 25 \%$

- $\quad$ Skor 2 diberikan jika $25 \%<\mathrm{X} \leq 50 \%$

- $\quad$ Skor 3 diberikan jika $50 \%<\mathrm{X} \leq 75 \%$

- $\quad$ Skor 4 diberikan jika $X>75 \%$

$\mathrm{X}$ adalah banyaknya siswa yang aktif melakukan kegiatan menurut descriptor

Dari hasil observasi asesmen kegiatan siswa di siklus I pada pertemuan pertama, kedua dan ketiga terlihat siswa masih tergolong pasif karena datanya menunjukkan hasil di bawah target keaktipan siswa belum mencapai minimal $80 \%$

\section{Data Hasil Penelitian Tindakan Kelas Siklus I}

Tabel 2 Akumulasi hasil belajar passing (chest pass) XUPW SMK Negeri 4 Mataram

\begin{tabular}{|c|c|c|c|c|c|c|}
\hline $\mathrm{NO}$ & Kwalifikasi & $\begin{array}{l}\text { Jumlah } \\
\text { Siswa }\end{array}$ & Persentase & Kategori & Target & Kesimpulan \\
\hline 1 & Sangat Baik & 3 & 7,14 & \multirow{3}{*}{$\begin{array}{c}\text { Tuntas } \\
26 \text { Orang } \\
=61,9 \%\end{array}$} & \multirow{3}{*}{$\begin{array}{c}\text { Secara } \\
\text { klasikal } \\
75 \% \\
\text {,individu } \\
70 \%\end{array}$} & \multirow{3}{*}{$\begin{array}{c}\text { Belum } \\
\text { mencapai } \\
\text { target maka } \\
\text { dilanjutkan } \\
\text { ke siklus } 2\end{array}$} \\
\hline 2 & Baik & 16 & 38,1 & & & \\
\hline 3 & Cukup & 7 & 16,66 & & & \\
\hline 4 & Kurang & 16 & 38,09 & \multirow{2}{*}{$\begin{array}{c}\text { Belum } \\
\text { tuntas } \\
16=38,09\end{array}$} & & \\
\hline 5 & $\begin{array}{l}\text { Sangat } \\
\text { Kurang }\end{array}$ & 0 & 0 & & & \\
\hline & Total & 42 & $100 \%$ & & & \\
\hline
\end{tabular}


Pada siklus I Akumulasi ketuntasan siswa terhadap materi passing (chest pass) mencapai 61,90\% (26 siswa), dan tidak tuntas 38,09 \% (16 siswa) bila dikonpersikan dengan tingkat penguasaan kompetensi yang berlaku di SMK Negeri 4 Mataram untuk mata pelajaran penjaskes berada pada rentangan 0- 49\% sangat kurang, sedangkan perolehan untuk masingmasing siswa dapat dilihat pada lampiran

Dari analisa pada siklus I maka ketuntasan siswa secara klasikal terhadap materi passing (chest pass) dalam cabang bolabasket sebagai berikut: Jumlah Siswa tuntas KB $=26 / 42 \times 100$ $\%=61,90 \%$

Dari tingkat ketuntasan secara klasikal terhadap materi passing (chest pass) dalam cabang olah raga bolabasket sebesar $61,90 \%$ pada siklus I. Penelitian ini di lanjutkan ke siklus II karena belum mencapai target ketuntasan secara klasikal $\geq 85 \%$.

\section{Observasi/Evaluasi}

Catatan dari hasil pengamatan Supervisi menyatakan bahwa proses pembelajaran pada akhir siklus I masih ada beberapa kendala hal ini tergambarkan dalam setiap pertemuan belum ada keaktifan siswa secara signifikan. Adapun beberapa kelemahan yang diperoleh antara lain

1. Pada pertemuan I ternyata siswa masih banyak yang bersifat individu, egois tidak mau menerima anggota kelompoknya, tidak mau menerima pendapat rekannya dalam satu kelompok apalagi terhadap kelompok lain.

2. Siswa enggan untuk melakukan karena bolanya berat, ingin bermain yang lain, takut cedra dan banyak macam alasannya

3. Belum ada kolaborasi antar siswa, baik dalam kelompoknya maupun dengan kelompok lain

4. Banyak siswa sangat menyulitkan dalam pembentukan kelompok

5. Belum mengerti bahwa passing(chest pass) yang dilakukan adalah untuk dirinya dalam bermain bola basket dan kelompoknya

6. Dalam pelaksanaan Team Asissted Individulization (TAI) hasilnya belum memuaskan. Karena ada siswa yang melakukan passing(chest pass) hanya sekedar mendorong saja dan ada yang tidak mengiraukan teknik passing(chest pass), bahkan banyak siswa yang tangannya Cuma digerakan saja dan banyak bermain tidak memperhatikan, bahkan ada siswa dari kelompok yang lain melihat hasil passing(chest pass) yang dilakukan tidak benar sehingga menui protes dari kelompok yang merasa dirugikan.

Kemudian sebagai reward dan Funisment, guru memberikan penghargaan berupa ucapan selamat kepada kelompok yang sudah memenuhi kriteria dalam bolabasket

\section{Refleksi Siklus 1}

Hasil diskusi antaran peneliti dengan guru observer tentang kekurangan yang terjadi pada siklus I perlu direncanakan perubahan perlakuan di siklus II dengan cara mengefektifkan langkah langkah pembelajaran dan merangsang keatifan siswa dalam beraktifitas :

1. Memfokuskan siswa agar bekerja dalam satu kelompok saling memberi dan menerima masukan baik dari sesama kelompok dengan kelompok lain bahkan minta bantuan ke guru

2. Menekankan tehnik yang tepat, serta bermain dengan berbagai macam variasi sehingga mampu menghilangkan rasa kecemasan

3. Memfokuskan kolaborasi antar kelompok, karena kelompok lain sebagai control dan bukan sebagai saingan

4. Siswa di perkenankan memilih kelompok sendiri tetapi guru mengatur secara heterogen dan ratio jumlah kelompok

5. Memberikan penjelasan pentingnya bekerjasama untuk mencapai tujuan guna meningkatkan kompetensi secara individu

6. kesungguhan dalam mengikuti pembelajaran sebagai wujud dari tanggung jawab secara individu dan kelompok sebagai prasarat pembentukan karakter 


\section{Hasil Penelitian Pada Siklus II}

Berikut ini ditampilkan data hasil pengamatan observer selama mengikuti pembelajaran pada siklus II

Tabel 3. Hasil Pantauan proses mengajar dan belajar siswa pada saat mengikuti pembelajaran passing (Bounce pass) di kelas X UPW SMK Negeri 4 Mataram pada siklus II.

\begin{tabular}{|l|l|l|l|}
\hline NO & Kegiatan Observer & $\begin{array}{l}\text { Aktivitas kegiatan } \\
\text { Guru 20 Asesmen }\end{array}$ & $\begin{array}{l}\text { Aktivitas kegiatan } \\
\text { Siswa15 Asesmen }\end{array}$ \\
\hline 1 & Asesmen observasi & & $\begin{array}{l}\text { Tercapai 11,5 = } \\
76,67 \%\end{array}$ \\
\hline 2 & $\begin{array}{l}\text { Prosentase Asesmen yang } \\
\text { muncul siklus II pada } \\
\text { pertemuan 1 }\end{array}$ & Tercapai 15=75\% & $\begin{array}{l}\text { Tercapai 12,2 }=81,3 \\
\%\end{array}$ \\
\hline 3 & $\begin{array}{l}\text { Prosentase akumulasi } \\
\text { Asesmen yang muncul } \\
\text { menurut Observer siklus II } \\
\text { pada pertemuan 2 }\end{array}$ & Tercapai 18=90\% & $\begin{array}{l}\text { Tercapai 13,8 =92 } \\
\%\end{array}$ \\
\hline 4 & $\begin{array}{l}\text { Prosentase akumulasi } \\
\text { Asesmen yang muncul } \\
\text { menurut Observer siklus II } \\
\text { pada pertemuan 3 }\end{array}$ & Tercapai 20=100\% & \\
\hline
\end{tabular}

\section{Hasil Data Penelitian Siklus II}

Tabel 4 Akumulasi hasil belajar passing (Bounce pass) di kelas XUPW SMK Negeri 4 Mataram pada siklus II.

\begin{tabular}{|c|c|c|c|c|c|c|}
\hline $\mathrm{NO}$ & Kwalifikasi & $\begin{array}{c}\text { Jumlah } \\
\text { Siswa }\end{array}$ & Persentase & Kategori & Target & Kesimpulan \\
\hline 1 & Sangat Baik & 7 & 16,66 & \multirow{3}{*}{$\begin{array}{c}\text { Tuntas } \\
38 \text { orang } \\
=90,47 \%\end{array}$} & Secara & \multirow{6}{*}{$\begin{array}{c}\text { Target telah } \\
\text { tercapai } \\
\text { minimal } 75 \\
\% \text { bahkan } \\
\text { terlampoi } \\
\text { maka } \\
\text { penelitian } \\
\text { ini di } \\
\text { hentikan }\end{array}$} \\
\hline 2 & Baik & 26 & 61,9 & & klasikal & \\
\hline 3 & Cukup & 5 & 11,9 & & $\begin{array}{c}75 \% \\
\text {,individu } \\
70 \%\end{array}$ & \\
\hline 4 & Kurang & 4 & 9,52 & \multirow{2}{*}{$\begin{array}{c}\text { Belum } \\
\text { tuntas } 4 \\
\text { Orang = } \\
9,52 \%\end{array}$} & & \\
\hline 5 & $\begin{array}{l}\text { Sangat } \\
\text { Kurang }\end{array}$ & 0 & 0 & & & \\
\hline & Total & 42 & $100 \%$ & & & \\
\hline
\end{tabular}

Pada siklus II akumulasi tingkat ketuntasan terhadap materi passing (Bounce pass) 90,47 \% (38 Orang) dan tidak tuntas 9,52 \% (4 Orang) bila di konversikan dengan tingkat penguasaan kompetensi yang berlaku di SMK Negeri 4 Mataram untuk mata pelajaran penjas berada pada rentangan $90 \%$ - $100 \%$ dalam kategori sangat baik, sedangkan perolehan nilai pada masing-masing siswa dapat dilihat dari lampiran.

Dari analisa data pada siklus II, maka ketuntasan klasikal pada materi passing (Bounce pass) cabang olah raga bolabasket adalah sebagai berikut:

Dengan demikian secara umum dapat disimpulkan bahwa pada siklus II tingkat penguasaan siswa secara klasikal terhadap materi passing (Bounce pass) dalam cabang olah raga bolabasket dapat mencapai 90,47 \% dengan tingkat ketuntasan berada pada 90\% -100\% dalam kriteria sangat baik, sedangkan perolehan nilai untuk masing-masing siswa secara individu adalah untuk kategori sangat baik sebanyak 10 orang dengan presentase $23,80 \%$, 
kategori baik sebanyak 28 orang dengan presentase 66,66\%, kategori kurang sebanyak 4 orang dengan presentase $9,38 \%$ dengan tercapainya target tersebut maka penelitian ini dihentikan. Hal ini dikarenakan batas minimal penguasaan materi secara klasikal oleh siswa adalah $75 \%$ dan individual $70 \%$.

\section{Refleksi siklus II}

Kerjasama antara guru obeserver dengan guru peneliti dalam mengidentifikasi permasalahan yang muncul guna memperbaiki tehnik pembelajaran berikutnya. Permasalahan yang muncul dalam siklus II sudah dapat di minimalisir terbukti adanya perubahan secara signifikan terhadap hasil pembelajaran, Karena target keberasilan siswa dalam belajar secara individu dan klasikal terpenuhi maka penelitian ini di hentikan walaupun masih ada beberapa kekurangan asesmen keaktifan siswa seperti: memberikan tanggapan terhadap apa yang disampaikan oleh guru dan Mengajukan pendapat terhadap apa yang disampaikan oleh guru baik pada saat guru menjelaskan maupun dalam membuat kesimpulan bersama guru masih kurang karena pencapaiannya berkisar 25\% $<\mathrm{X} \leq 50 \%$ ( kategori kurang), hal ini di sebabkan karena ada sebagian siswa tidak nampak melakukan kedua asesmen tersebut,

\section{Pembahasan}

Berdasarkan hasil analisis data, pemberian tindakan pada siklus I kurang berhasil untuk mengajak siswa untuk berperan aktif dalam pembelajaran. Hal ini dapat dilihat dari skor ratarata hasil belajar siswa, dan ketuntasan belajar belum memenuhi tuntutan kurikulum yaitu 75 $\%$. Hal ini terbukti dari refleksi I masih terdapat hambatan-hambatan yang terjadi adalah (1) belum adanya kerjasama yang baik pada maing-masing kelompok dalam melaksanakan tugasnya masing-masing. (2) ada beberapa siswa masih sulit dalam melakukan (chest pass). (3) siswa masih mempelajari berbagai jenis keterampilan secara mandiri tanpa mau bekerjasama dengan kelompoknya.

Berdasarkan hambatan-hambatan yang dihadapi pada siklus I maka pada siklus II guru/peneliti mengadakan penyempurnaan dan perbaikan terhadap kendala-kendala yang muncul pada siklus I.

Sesuai dengan kendala yang dihadapi, untuk perbaikan kualitas pembelajaran dan hasil belajar pada siklus II guru harus mengurangi keterlibatan aktif di dalam proses pembelajaran dan memberikan kesempatan yang seluas-luasnya kepada siswa untuk belajar di dalam kelompoknya. Hal ini sesuai dengan pendapat dari Sudana (2000: 17) yang mengatakan bahwa dengan siswa belajar secara kooperatif maka siswa akan terbiasa mengerjakan tugas secara mandiri dan kelompok, menciptakan suasana belajar yang menyenangkan, meningkatkan interaksi antar sesama siswa, termasuk siswa yang kurang mampu sehingga akan berpengaruh pada hasil belajar yang dicapai.

Dari berbagai kendala yang dirasakan oleh peneliti di siklus I, pada pembelajaran selanjutnya dievaluasi dan merencanakan tindakan yang lebih akurat sehingga di harapkan mampu menaikan derajat kualitas pembelajaran:

1. Membuat peraturan yang ditujukan kepada kelompok jika kelompoknya salah dalam melakukan gerakan passing (bounce pass) di berikan hukuman terhadap kelompok tersebut sehingga interaksi siswa dalam kelompoknya akan sangat antusias untuk berlatih sampai semua anggota dalam kelompok tersebut benar-benar yakin bahwa anggota kelompoknya tidak akan melakukan kesalahan. Dan sebaliknya jika kelompok tersebut melakukan gerakan (bounce pass) itu benar maka kelompok itu akan di berikan penghargaan berupa pengakuan dari guru pengajar sehingga nantinya akan berdampak positif terhadap hasil belajar yang akan dicapai.

2. Memvariasikan bentuk-bentuk latihan bounce pass agar siswa lebih menyenangkan dalam melakukan latihan

3. Melakukan kompetisi secara individu dalam kelompok sehingga ada semacam tanggung jawab dalam berusaha menjadi yang terbaik 
4. Sesuai dengan karakteristik dari pembelajaran kooperatif tipe Team Assisted Individualization (TAI), guru harus dapat memberikan kesempatan belajar kepada siswa di dalam suatu kelompok belajar yang telah dibentuk dan guru mampu menciptakan suasana belajar yang ceria, gairah dan responsif.

Dari hasil analisis data pada siklus II, telah terjadi peningkatan hasil belajar dan ketuntasan belajar telah mencapai 90,47 \%. Hasil belajar dan ketuntasan klasikal pada siklus II telah mencapai tuntutan kurikulum, dan telah memenuhi kriteria keberhasilan yang telah peneliti tetapkan. Hasil yang dicapai dalam penelitian ini senada dengan pendapat Sudana (2002: 35) yang menyatakan bahwa pembelajaran dengan model kooperatif akan memberikan motifasi yang kuat kepada siswa untuk mengikuti kegitatan pembelajaran, karena siswa diberikan kesempatan yang luas dalam pelaksanaan pembelajaran itu menjadi milik mereka sendiri. Pembelajaran menjadi sangat menyenangkan karena siswalah yang aktif melaksanakan kegiatan belajar. Tentunya motivasi belajar ini berpengaruh pada ketercapaian hasil belajar siswa. Selain itu pembelajaran kooperatif dengan model pembelajaran kelompok kecil akan menumbuhkan suasana demokratis dalam pembelajaran sehingga akan terjadi diskusi untuk saling belajar membelajarkan diantara siswa (Sudjana dalam Parnata,2004: 92).

Dilihat dari hasil-hasil yang diperoleh, secara umum penelitian ini dapat dikatakan telah dapat menjawab permasalahan yang telah dirumuskan atau dengan kata lain telah dapat mencapai tujuan yang diharapkan. Namun demikian hasil ini masih belum sempurna karena dari hasil yang diperoleh masih ada siswa yang bermasalah dalam mencapai hasil belajar yang di targetkan, hal tersebut disebabkan oleh beberapa kendala yang dihadapi, yaitu : (1) ada beberapa siswa yang tidak hadir pada saat berlangsungnya proses pembelajaran karena siswa sakit,(2) waktu yang tersedia untuk penelitian terbatas sehingga proses pembelajaran belum dapat terlaksana secara utuh terutama pada siswa yang memilki keterampilan rendah,(3) ketidak tersedianya bola Untuk melakukan olah raga bola basket yang sebenarnya, sedangkan peneliti hanya menggunakan bola basket yang tidak selayaknya dipakai sebagai alat untuk melakukan pembelajaran passing dan dimodifikasi hal ini kemungkinan bagi siswa yang belum tuntas mengalami kendala dalam hal keraguan untuk melakukan gerakan passing yang sesungguhnya.

\section{KESIMPULAN}

Berdasarkan hasil analisa data pada, maka ditarik suatu kesimpulan bahwa pada siklus 1 materi pembelajaran passing (chest pass) belum dikatakan tuntas disebabkan karena hasil dari penilaian siswa belum mencakupi hasil yang maksimal kebanyakan siswa belum tuntas dalam gerakan passing (chest pass) sehingga dapat disimpulkan yang tuntas 61,90\% (26 siswa), dan siswa yang tidak tuntas mencakupi $38,09 \%$ (16 siswa) sehingga pelajaran penjas pada rentangan 35-74\% kurang/tidak efektif. sehingga pada siklus 2 akumulasi ketuntasan siswa terhadap materi passing (bounce pass) dapat disimpulkan sangat baik dikarenakan kebanyakan siswa menguasai gerakan passing (bounce pass) karena penerapan model pembelajaran TAI ini efektif maka terjadi perubahan dari siklus I ke siklus II sebanyak $25 \%$.

\section{DAFTAR PUSTAKA}

Agus Suardana. (2006). Jurnal Pendidikan dan Pengajaran IKIP Negeri Singaraja

Arikunto, Suharmani. (2006). Prosedur Penelitian. Cetakan Kesebelasan. Yogyakarta: PT. Rinika Cipta

Cholik dan Rusli Lutan. (1997). Pendidikan Jasmani dan Kesehatan.Depdikbut, Dirjen Dikti Bagian Pengembangn PGSD.

Depdiknas, Direktorat Jenderal Pendidikan Dasar dan Menengah, Dikretorat Pendidikan Lanjutan Pertama. (2002). Manajemen Peningkatan Mutu Berbasis Sekolah, Pembelajaran dan Kontekstual. Jakarta: Depdiknas.

Dimyanti dan Mudjiono. (2006). Belajar dan Pembelajaran, Jakarta : PT. Rineka Cipta 
Hamalik. (2007). Manajemen Pengembangan Kurikulum, Bandung : PT. Remaja Rosda Karya Hasibuan dan Moedjiono. (1995). Proses Belajar Mengajar. Cetakan Ketujuh. Bandung: PT. Remaja Rosdakarya.

Jason, dan Halubec (Dalam Anggraeni Yulia, 2003).Penerapan Pembelajaran Kooperatif Team Assisted Individualization dengan Unpan Balik Terseruktur Untuk Meningkatkan Prestasi Belajar Matematika.Skripsi. (Tidak Diterbitkan). Jurusan Pendidikan MIPA. IKIP Negeri Sigaraja.

Lutan dan Mutohir. (1999). Pendidikan Jasmani dan Kesehatan. Jakarta: Direktorat Jenderal Pendidikan Tinggi dan Menengah Bagian Proyek Penggembangan Pendidikan Guru Sekolah Dasar, Departemen Pendidikan dan Kebudayaan.

Nur Muhammad. (1998). Prosedur Penelitian Suatu Pendekatan Praktik, Jakarta, Rineksa Cipta.

Nurhasan. (1990). Tes dan Pengukuran Dalam Penjas Serta Prinsip-prinsip Pelaksanaannya. Jakarta: Departemen Pendidikan dan Kebudayaan.

Roestiyah. (1989). Strategi Belajar Mengajar. Jakarta: Bina Aksara.

Sajoto. (1989). Permainan Bola Basket dan Peraturan Praktis. Semarang: Fakultas Keguruan Ilmu Pendidikan IKIP Semarang.

Sarumpaet, ddk. (1992). Permainan Bola Basket. Jakarta: Direktorat Jenderal Pendidikan Tinggi Proyek Pembinaan Tenaga Kependidikan, Depdikbud.

Slvin, R.E. (1993). Cooperative Learning Theory, Research, and Practice.Second Edsion.Hopkins University.

Syarifudin. (1997). Pendidikan Jasmani dan Kesehatan I, Jakarta, Grasindo

Soeprapto. (1979). Permainan dan Metodik untuk SGO. Jakarta: Depdikbud.

Sudjana. (1992). Metode Statika. Bandung:Tarsito

Soemadi Suryabrata. (1995). Metodologi Penelitian. Jakarta: Rineka Cipta.

Sumantom, et.al. (1992). Strategi Belajar Mengajar. Jakarta: Depdikbud

Soemadi Suryabrata. (1995). Metodologi Penelitian. Jakarta: Rineka Cipta.

Sudana, Wayan. (1999). Pemberdayan Metode Kooperatif Sebagai Motivasi dan Prestasi Belajar. Laporan Penelitian. (Tidak Diterbitkan). Jurusan pendidikan MIPA, IKIP Negeri Singaraja.

Yogi I Kadek. (2007). Penerapan Model Pembelajaran Kooperatif Tipe Teams-GamesTournament (TGT) Untuk Meningkatkan Hasil Belajar Passing Dalam Permaianan Bola Basket Pada Siswa Kelas XI IA 2 SMAN 4 Sigaraja. 